\title{
Predisposing factors and impact of healthcare-associated infections in patients with status epilepticus
}

\author{
Factores predisponentes e impacto de las infecciones asociadas a los cuidados de salud \\ en pacientes con estatus epiléptico
}

\author{
Dannys RIVERO RODRIGUEZZ1,2, Claudio SCHERLE MATAMOROS ${ }^{1}$, Daniela DICAPUA SACOTO',2, \\ Sara GARCIA-PTACEK ${ }^{3,4}$, Yanelis PERNAS SANCHEZ ${ }^{5}$, Graham PLUCK ${ }^{1}$
}

\begin{abstract}
Background: Few studies have evaluated the incidence, predisposing factors and impact of healthcare-associated infections (HCAls) in relation to outcomes among patients with status epilepticus (SE). Objective: To investigate the variables associated with development of HCAls among patients with SE and the impact of factors relating to HCAls on mortality at three months. Methods: This study was a retrospective analysis on our prospectively collected dataset, from November 2015 to January 2019. The sample included all consecutive patients diagnosed with SE who were treated at Hospital Eugenio Espejo during that period. In total, 74 patients were included. Clinical variables such as age, etiology of SE, Charlson comorbidity index (CCl), hospital length of stay, refractory SE (RSE) and outcomes were analyzed. Results: HCAls were diagnosed in 38 patients (51.4\%), with a preponderance of respiratory tract infection (19;25.7\%). Prolonged hospital length of stay $(\mathrm{OR}=1.09 ; 95 \% \mathrm{Cl} 1.03-1.15)$ and $\mathrm{CCl} \geq 2(\mathrm{OR}=5.50 ; 95 \% \mathrm{Cl} 1.37-22.10)$ were shown to be independent variables relating to HCAls. HCAls were associated with an increased risk of mortality at three months, according to Cox regression analysis ( $\mathrm{OR}=2.23 ; 95 \% \mathrm{Cl} 1.08-4.58)$, and with infection caused by Gram-negative microorganisms (OR=3.17;95\% Cl 1.20-8.39). Kaplan-Meier curve analysis demonstrated that HCAls had a negative impact on the survival rate at three months (log rank=0.025). Conclusions: HCAls are a common complication among Ecuadorian patients with SE and were related to a lower survival rate at three months. Prolonged hospital length of stay, RSE and CCl $\geq 2$ were associated with the risk of developing HCAls.
\end{abstract}

Keywords: Status Epilepticus; Cross Infection; Mortality; Epilepsy.

\section{RESUMO}

Antecedentes: Pocos estudios han evaluado la incidencia, los factores predisponentes y el impacto de las infecciones asociadas a los cuidados de salud (IACS) en pacientes con Estatus Epiléptico (EE). Objetivo: Evaluar los factores predisponentes de IACS en pacientes con EE y su impacto evolutivo después de tres meses. Métodos: Se realizó un análisis retrospectivo de los datos recogidos prospectivamente en nuestra base de datos, desde noviembre de 2015 hasta enero de 2019. Se incluyeron todos los pacientes diagnosticados y consecutivamente tratados con EE, en el Hospital Eugenio Espejo, durante ese periodo. En total, 74 pacientes fueron incluidos. Se analizaron variables clínicas y evolutivas. Resultados: Las IACS fueron identificadas en 38 pacientes (51,4\%), con predominio de infecciones respiratorias (25,7\%). Los factores asociados con el desarrollo IACS fueron la estadía hospitalaria prolongada (OR=1,09, IC95\% 1,03-1,15) y el índice de Charlson (ICH) $\geq 2(\mathrm{OR}=5,50$, IC95\% 1,37-22,10). La regresión de Cox demostró un incremento significativo de la mortalidad en los pacientes con IACS (OR=2,23, IC95\% 1,08-4,58) y en las causadas por gérmenes gram-negativos (OR=3,17, IC95\% 1,20-8,39). La curva de Kaplan Meier evidenció el impacto desfavorable de las IACS (log rank=0.025) en la evolución de los pacientes después de los tres meses. Conclusiones: Las IACS fueron complicaciones frecuentes en los pacientes ecuatorianos con EE y fueron asociadas con una menor supervivencia después de los tres meses. Las variables como la estadía hospitalaria prolongada, el EE refractario y el ICH $\geq 2$ fueron identificados como factores de riesgo para sufrir una IACS.

Palabras clave: Estado Epiléptico; Infección Hospitalaria; Mortalidad; Epilepsia.

\footnotetext{
'San Francisco University of Quito, Neuroscience Institute, Quito, Ecuador.

${ }^{2}$ Eugenio Espejo Hospital, Neurology Department, Quito, Ecuador.

${ }^{3}$ Karolinska Institutet, Division of Clinical Geriatrics, Center for Alzheimer Research, Department of Neurobiology, Care Sciences and Society, Huddinge, Sweden. 4Södersjukhuset, Department of Internal Medicine, Neurology Section, Stockholm, Sweden.

${ }^{5}$ Andrade Marin Hospital, Department of Internal Medicine, Quito, Ecuador.

Dannys RIVERO RODRÍGUEZ (DD https://orcid.org/0000-0001-5612-932X; Claudio SCHERLE MATAMOROS (iD https://orcid.org/0000-0002-9315-7212; Daniela DICAPUA SACOTO (D) https://orcid.org/0000-0002-5235-3479; Sara GARCIA-PTACEK (iD https://orcid.org/0000-0002-1537-6129; Yanelis PERNAS SANCHEZ (D) https://orcid.org/0000-0002-4512-5013; Graham PLUCK (DD https://orcid.org/0000-0002-0368-0051

Correspondence: Dannys Rivero Rodríguez; E-mail: dannyriverorodriguez@gmail.com.

Conflict of interest: The authors have no conflicts of interest to declare.

Support: This research did not receive any specific grant from funding agencies in the public, commercial or not-for-profit sectors.

Authors' contribution: DRR: designed the study, collected and processed the data, performed the statistical analyses, performed the analysis on the results and drafted the manuscript. CSM: participated in treatment of the patients, collected the data and reviewed the final manuscript. DDS: participated in treatment of the patients and drafted the final manuscript. SGP: revised the manuscript for scientific content. YP: performed the statistical analysis. GP: revised the final manuscript.

Received on October 6, 2019; Received in its final form on June 9, 2020; Accepted on July 22, 2020.
} 


\section{INTRODUCTION}

Status epilepticus (SE) is a frequent neurological emergency with high morbidity, mortality and costs for healthcare systems ${ }^{1}$. In many patients, SE is a complication of a metabolic disturbance, and in other patients, it is a consequence of direct injury to the brain.

Healthcare-associated infections (HCAIs) and SE have a bidirectional etiological relationship. In one direction, SE may be caused by infections of the central nervous system or may be a complication of systemic infection. In the other direction, patients with refractory SE (RSE) require sedative treatment in the neurocritical care unit and long-term hospitalization. In this scenario, HCAIs are a common complication that may affect up to $36 \%$ of all patients ${ }^{2}$.

Over recent years, evidence has accumulated relating to infections as a relevant factor in the final outcomes of patients with SE. However, only a few studies have evaluated the incidence, predisposing factors and impact of HCAIs regarding the outcomes of such patients ${ }^{3,4,5}$. This lack of information is most prominent in developing countries such as Ecuador, where the scenario may be more common than in developed countries. A metaanalysis on the burden of endemic HCAIs in intensive care units found an incidence in developing countries at least three times higher than what was reported from the USA (47.9 vs 13.6 per 1,000 patients-day) ${ }^{6}$. Furthermore, there is a lack of research on the factors relating to HCAIs, such as type of bacteria, infection site and antibiotic resistance, and the influence of these factors on the final outcomes of patients with SE.

The aims of this study were to evaluate the variables associated with development of HCAIs in Ecuadorian patients with SE and the impact of factors relating to HCAIs on mortality outcomes at three months.

\section{METHODS}

\section{Design and setting}

This study was a retrospective analysis on our prospectively collected dataset, from November 2015 to January 2019. The sample included all consecutive patients diagnosed with SE who were treated at Hospital Eugenio Espejo during that period. Hospital Eugenio Espejo is the main tertiary-level public care center in Quito, and it is a referral center for 12 secondary-level hospitals in the highland and Amazon regions.

A total of 79 patients were initially recruited, taking into consideration the inclusion and exclusion criteria listed below.

\section{Inclusion criteria:}

- Age greater than 18 years old.

- Diagnosis of SE in accordance with the ILAE definition proposed in $2015^{7}$.
- Or diagnosis of non-convulsive SE (NCSE) in accordance with the Salzburg criteria ${ }^{8}$.

\section{Exclusion criteria}

- Patients with signs of infection ( fever $\geq 38^{\circ} \mathrm{C} ; \mathrm{WBC} \geq 12,000$; respiratory tract, urinary tract or central nervous system infection suspected) before hospital admission or during the first 72 hours after admission.

- Patients with systemic inflammatory response syndrome with unknown infection site and negative cultures or negative for antigen.

- Missing follow-up and/or impossibility of registering all the required variables.

At the end of the selection process, 74 patients were included (Figure 1). All of them were followed up at the ambulatory clinic of Hospital Eugenio Espejo at least twice, for three months after hospital discharge. Two patients were lost from follow-up and two suffered infections (respiratory and urinary tract infections) before hospital admission or during the first 72 hours after admission. One patient was excluded due to impossibility of identifying the infection site and HCAI agent. All patients were treated following the treatment guidelines of the Neurocritical Care Society?

Clinical variables such as sex, age, level of consciousness (according to the Glasgow coma score) ${ }^{10}$ at the beginning of the SE and the chief complaint at the initial neurological evaluation were studied. The etiology of SE was considered

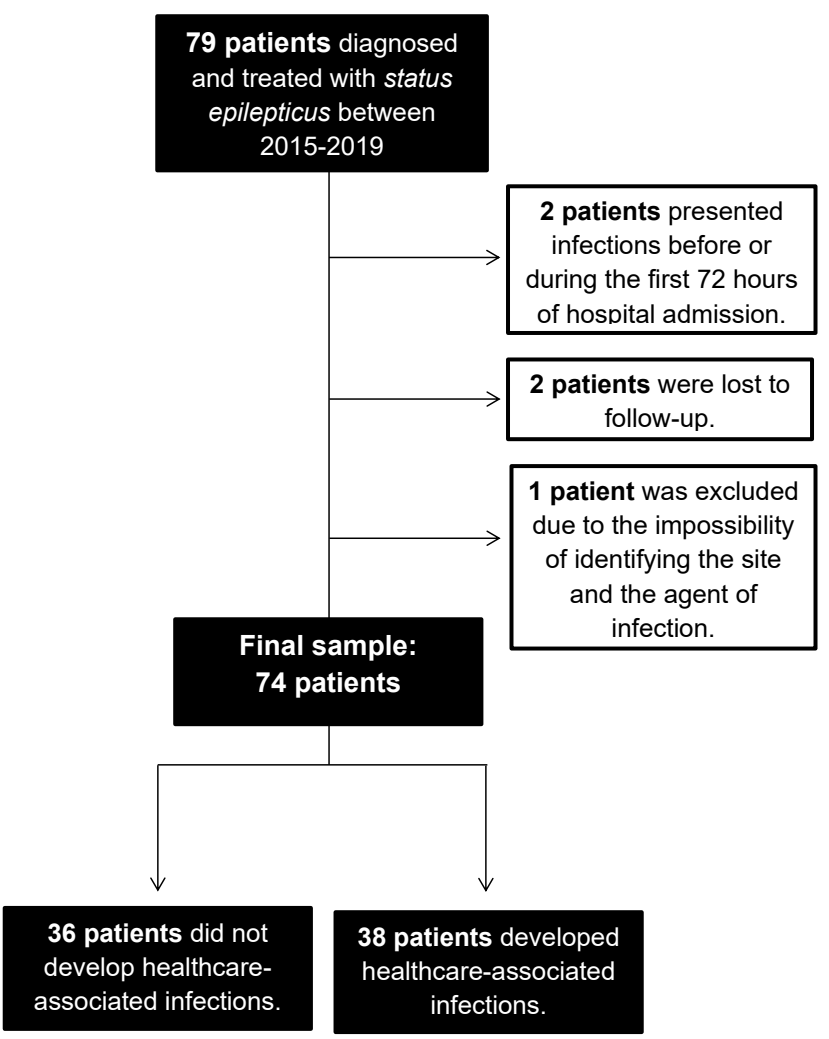

Figure 1. Diagram of flow's patients. 
in accordance with the proposed ILAE guidelines for epidemiological studies on epilepsy ${ }^{11}$. The following groups were considered: cerebrovascular diseases, metabolic diseases, tumors, traumatic brain injury, autoimmune encephalitis, anoxic/hypoxic lesions, histories of epilepsy with poor compliance with antiepileptic drugs and mixed causes (when the patient had two or more probable causes with a temporal relationship). The Charlson comorbidity index (CCI) was used to evaluate comorbidities ${ }^{12}$. Refractory SE (RSE) was defined as a lack of response to at least two standard lines of antiepileptic drugs (at least midazolam-phenytoin) ${ }^{13}$. HCAIs were registered following the recommendations of the Centers for Disease Control and Prevention (CDC) criteria, considering the following ${ }^{14}$ : infection site (respiratory, urinary, central nervous system, bacteremia, etc.), type of bacteria related to the infection, Gram stain classification, whether the bacteria was multidrug-resistant, disseminated infection (bacteremia, or two or more sites with a positive culture of the same bacterium) and mechanism of resistance, i.e. extended-spectrum beta-lactamase (ESBL) or carbapenemase-producing bacteria (CPB). Infectious complications that occurred over the hospitalization period following the SE diagnosis and up to seven days before SE were assessed. All patients were evaluated using the Rankin scale ${ }^{15}$ at hospital discharge and three months later. Mortality during hospitalization and at three months was considered.

\section{Statistical analysis}

The data were summarized as the mean \pm standard deviation (SD) and range for continuous variables, and as the frequency for categorical variables. Development of HCAIs was treated as a binary categorical variable. A univariate analysis was performed to identify factors associated with development of HCAIs. The chi-square and Fisher exact tests were used for categorical variables and Student's t-test for comparison of means in continuous variables, as appropriate. $\mathrm{P}$ values $<0.05$ were considered statistically significant. Binary logistic regression was performed to determine variables that were related independently to development of HCAIs in our patients. A Cox regression was calculated to evaluate the HCAI factors relating to mortality at three months. Odds ratios (ORs) were estimated for magnitude of effect with $95 \%$ confidence intervals (95\%CI). Kaplan-Meier curves were performed to evaluate the patients' survival rate according to the HCAI diagnosis and the mechanism of resistance of the bacterium that caused the HCAI. Log-rank tests showing $\mathrm{p} \leq 0.05$ were considered statistically significant.

\section{Ethical approval}

The ethical principles set forth in the 1964 Helsinki declaration were followed. Informed consent was obtained from all individual participants included in the study, or from their relatives, in cases of altered judgment or impaired level of consciousness. The personal data of all patients were protected. The execution of this study was approved by the institutional ethics committee.

\section{RESULTS}

A total of 74 patients were evaluated. Convulsive SE was more frequently identified than non-convulsive SE (82.4 vs $17.6 \%$, respectively). Acute symptomatic etiology of SE was identified in 40 patients (54.1\%). Considering the etiology of SE according to groups, cerebrovascular plus mixed causes were the most prevalent causes, occurring in $36.5 \%$ of the patients. HCAIs were diagnosed in 38 patients $(51.4 \%)$ with a preponderance of respiratory tract infection (19; 25.7\%). E. coli and Staphylococcus were found to be the most common bacteria isolated in cultures: respectively, 10 (13.5\%) and $21(28.4 \%)$ of the patients developed disseminated infections due to these bacteria. Hospital mortality reached $35.1 \%$ and unfavorable outcome (Rankin 4 to 6 ) affected $63.5 \%$ of the patients at three months (Table 1).

Table 1. General characteristics of the patients.

\begin{tabular}{|c|c|}
\hline & $\begin{array}{c}\text { Number of patients } \\
(n=74) \\
n(\%) \text { or mean } \pm \text { SD }\end{array}$ \\
\hline Age (years) & $50.5 \pm 24.4$ \\
\hline Sex (male) & $49(66.2)$ \\
\hline Epilepsy history & $27(36.5)$ \\
\hline \multicolumn{2}{|l|}{ Status epilepticus } \\
\hline Convulsive & $61(82.4)$ \\
\hline Non-convulsive & $13(17.6)$ \\
\hline Glasgow coma scale & $10.6 \pm 3.6$ \\
\hline \multicolumn{2}{|l|}{ Initial symptom } \\
\hline Seizure & $30(40.5)$ \\
\hline Level of consciousness disorder & $23(31.1)$ \\
\hline Agitation & $2(2.7)$ \\
\hline Focal neurological deficit & $2(2.7)$ \\
\hline CNS infection-related symptom & $2(2.7)$ \\
\hline Seizure+level of consciousness disorder & $15(20.3)$ \\
\hline \multicolumn{2}{|l|}{ Etiology (ILAE) } \\
\hline Acute symptomatic & $40(54.1)$ \\
\hline Remote symptomatic & $18(24.3)$ \\
\hline Progressive symptomatic & $12(16.2)$ \\
\hline Idiopathic/cryptogenic & $4(5.4)$ \\
\hline \multicolumn{2}{|l|}{ Etiology (groups) } \\
\hline Metabolic & $7(9.5)$ \\
\hline CNS infections & $4(5.4)$ \\
\hline Electrolyte disorders & $1(1.4)$ \\
\hline Anoxia/hypoxia & $3(4.1)$ \\
\hline Cerebrovascular disease & $13(17.6)$ \\
\hline
\end{tabular}


Table 1. Continuation.

\begin{tabular}{|c|c|}
\hline & $\begin{array}{c}\text { Number of patients } \\
(n=74) \\
n(\%) \text { or mean } \pm \text { SD }\end{array}$ \\
\hline CNS tumors & $3(4.1)$ \\
\hline Traumatic brain injury & $5(6.8)$ \\
\hline Autoimmune & $3(4.1)$ \\
\hline Low antiepileptic drug level & $16(21.6)$ \\
\hline Mixed & $14(18.9)$ \\
\hline Cryptogenic+toxic & $5(6.8)$ \\
\hline \multicolumn{2}{|l|}{ SE severity (according to score) } \\
\hline STESS & $2.6 \pm 1.4$ \\
\hline mSTESS & $3.8 \pm 1.7$ \\
\hline EMSE-EAC & $45.4 \pm 24.0$ \\
\hline EMSE-ECLEG & $71.2 \pm 29.8$ \\
\hline EMSE-EACEG & $73.9 \pm 32.7$ \\
\hline Refractory SE & $39(52.7)$ \\
\hline \multicolumn{2}{|l|}{ Charlson comorbidity index } \\
\hline o or 1 & $26(35.2)$ \\
\hline 2 & $20(27.0)$ \\
\hline$\geq 3$ & $28(37.8)$ \\
\hline Hospital length of stay (days) & $29.8 \pm 33.3$ \\
\hline HCAls & $38(51.4)$ \\
\hline \multicolumn{2}{|l|}{ Bacterial type } \\
\hline E. coli & $10(13.5)$ \\
\hline Klebsiella & $8(10.8)$ \\
\hline Pseudomonas & $4(5.4)$ \\
\hline Staphylococcus & $10(13.5)$ \\
\hline Enterobacteriaceae & $2(2.7)$ \\
\hline Others+unknown germs & $4(5.5)$ \\
\hline Disseminated infections & $21(28.4)$ \\
\hline Gram-negative bacteria & $25(33.8)$ \\
\hline \multicolumn{2}{|l|}{ Infection site } \\
\hline CNS & $8(10.8)$ \\
\hline Respiratory tract infection & $19(25.7)$ \\
\hline Urinary tract infection & $5(6.8)$ \\
\hline Septic shock & $3(4.1)$ \\
\hline Unknown & $1(1.4)$ \\
\hline Skin and soft-tissue infection & $2(2.7)$ \\
\hline CPB & $9(12.2)$ \\
\hline ESBL & $10(13.5)$ \\
\hline Hospital mortality & $26(35.1)$ \\
\hline Mortality at three months & $34(45.9)$ \\
\hline $\begin{array}{l}\text { Unfavorable outcome at three months } \\
\text { (Rankin 4-6) }\end{array}$ & $47(63.5)$ \\
\hline
\end{tabular}

SD: standard deviation; CNS: central nervous system; SE: status epilepticus; HCAls: healthcare-associated infections; STESS: status epilepticus severity score; mSTESS: modified Rankin scale status epilepticus severity score; EMSE: epidemiology-based mortality score in status epilepticus (E, etiology; A, age; C, comorbidity; L, level of consciousness pre-treatment; EG, electroencephalography); CPB: carbapenemase-producing bacteria; ESBL: extended-spectrum beta lactamase.
Univariate analysis (Table 2) showed the factors that related to development of HCAIs. Cerebrovascular disease plus mixed etiology $(\mathrm{p}=002)$, RSE $(\mathrm{p}=0.01)$, prolonged hospital length of stay $(p \leq 0.01)$ and Charlson comorbidity index $(\mathrm{p}=0.001)$ were associated with increased risk of developing

Table 2. Univariate analysis on factors relating to development of healthcare-associated infections among Ecuadorian patients with status epilepticus.

\begin{tabular}{|c|c|c|c|}
\hline Factors & $\begin{array}{c}\text { Patients } \\
\text { without } \\
\text { HCAls } \\
n=36\end{array}$ & $\begin{array}{c}\text { Patients } \\
\text { with } \\
\text { HCAls } \\
n=38\end{array}$ & $p$-value \\
\hline Age & $50.5 \pm 26.1$ & $50.6 \pm 23.0$ & $0.99^{\circledR}$ \\
\hline Sex (male) & 24 & 25 & $1.00^{\circledR}$ \\
\hline Epilepsy history & 15 & 12 & $0.47^{\oplus}$ \\
\hline SE & & & $1.00^{\circledR}$ \\
\hline Convulsive & 30 & 31 & \\
\hline Non-convulsive & 6 & 7 & \\
\hline Initial symptom & & & $0.42^{\circledR}$ \\
\hline Seizure & 17 & 13 & \\
\hline $\begin{array}{l}\text { Level of consciousness } \\
\text { disorder }\end{array}$ & 10 & 13 & \\
\hline Agitation & 1 & 1 & \\
\hline Focal neurological deficit & 0 & 2 & \\
\hline $\begin{array}{l}\text { CNS infection-related } \\
\text { symptom }\end{array}$ & 0 & 2 & \\
\hline $\begin{array}{l}\text { Seizure+level of } \\
\text { consciousness disorder }\end{array}$ & 8 & 7 & \\
\hline Glasgow coma scale & $10.8 \pm 3.7$ & $10.5 \pm 3.4$ & $0.67^{\Omega}$ \\
\hline Etiology (ILAE) & & & $0.07^{\circledast}$ \\
\hline Acute symptomatic & 17 & 23 & \\
\hline Remote symptomatic & 7 & 11 & \\
\hline Progressive symptomatic & 8 & 4 & \\
\hline Idiopathic/cryptogenic & 4 & 0 & \\
\hline \multicolumn{4}{|l|}{ Etiology (group) } \\
\hline $\begin{array}{l}\text { Cerebrovascular } \\
\text { disease+mixed }\end{array}$ & 7 & 21 & $0.002^{\star \oplus}$ \\
\hline \multicolumn{4}{|l|}{ SE severity (according to score) } \\
\hline STESS & $2.6 \pm 1.4$ & $2.6 \pm 1.4$ & $0.98^{\Omega}$ \\
\hline mSTESS & $3.8 \pm 1.6$ & $3.9 \pm 1.8$ & $0.72^{\Omega}$ \\
\hline EMSE-EAC & $43.0 \pm 24.8$ & $47.6 \pm 23.3$ & $0.40^{\Omega}$ \\
\hline EMSE-ECLEG & $67.8 \pm 28.6$ & $74.5 \pm 31.0$ & $0.33^{\Omega}$ \\
\hline EMSE-EACEG & $69.3 \pm 32.2$ & $78.3 \pm 33.0$ & $0.24^{\Omega}$ \\
\hline Refractory SE & 13 & 26 & $0.01 * \circledast$ \\
\hline Charlson comorbidity index & & & $0.001^{* \oplus}$ \\
\hline 0 or 1 & 20 & 6 & \\
\hline$\geq 2$ & 16 & 32 & \\
\hline $\begin{array}{l}\text { Hospital length of stay } \\
\text { (days) }\end{array}$ & $15.6 \pm 11.7$ & $43.3 \pm 41.0$ & $0.000 \star \Omega$ \\
\hline
\end{tabular}

Continue.. 
Table 2. Continuation.

\begin{tabular}{lccc}
\hline Factors & $\begin{array}{c}\text { Patients } \\
\text { without } \\
\text { HCAls } \\
\mathrm{n}=36\end{array}$ & $\begin{array}{c}\text { Patients } \\
\text { with } \\
\text { HCAls } \\
\mathrm{n}=38\end{array}$ & p-value \\
\hline Hospital mortality & 9 & 16 & $0.09^{\circledR}$ \\
\hline Mortality at three months & 11 & 23 & $0.01^{\star{ }^{\circledR}}$ \\
$\begin{array}{l}\text { Unfavorable outcome at } \\
\text { three months (Rankin 4-6) }\end{array}$ & 19 & 28 & $0.09^{\circledR}$ \\
\hline
\end{tabular}

SE: status epilepticus; HCAls, healthcare-associated infections; STESS, status epilepticus severity score; mSTESS, modified Rankin scale status epilepticus severity score; EMSE, epidemiology-based mortality score in status epilepticus (E, etiology; A, age; C, comorbidity; L, level of consciousness pre-treatment; EG, electroencephalography); ${ }^{\star} p \leq 0.05$; ${ }^{\oplus} \mathrm{chi}$-square and Fisher exact tests; ${ }^{\oplus}$ Student's t-test.

HCAIs. Binary logistic regression (Table 3) demonstrated the independent variables relating to HCAIs. Associations with prolonged hospital length of stay (OR=1.09; 95\%CI 1.03-1.15) and Charlson comorbidity index $(\mathrm{OR}=5.50$; 95\%CI $1.37-$ 22.10) and a trend with RSE (OR=3.54; 95\%CI 0.96-13.10) were found.

HCAIs were associated with increased risk of mortality at three months, according to Cox regression analysis ( $\mathrm{OR}=2.23$; 95\%CI 1.08-4.58) (Table 4). Other factors relating to HCAIs that were linked to death at 90 days were infections caused by Gram-negative microorganisms $(\mathrm{OR}=3.17$; 95\%CI $1.20-$ 8.39) and carbapenemase-producing germs (OR=3.09; 95\% CI 1.30-7.34). Kaplan-Meier curve analysis (Figure 2) showed that presence of HCAIs (log rank=0.025) or infection due to $\mathrm{CPB}$ or microorganisms with ESBL (log rank=0.004) presented negative impacts on survival at three months.



Table 3. Logistic regression analysis on factors relating to development of healthcare-associated infections among Ecuadorian patients with status epilepticus.

\begin{tabular}{lccc}
\hline Factors & OR & $95 \% \mathrm{Cl}$ & $\mathrm{p}$-value \\
\hline $\begin{array}{l}\text { Cerebrovascular disease }+ \\
\text { mixed etiology }\end{array}$ & 2.44 & $0.62-9.59$ & 0.20 \\
Refractory SE & 3.54 & $0.96-13.10$ & 0.058 \\
\hline Hospital length of stay & 1.09 & $1.03-1.15$ & $0.001 *$ \\
Charlson comorbidity index $\geq 2$ & 5.50 & $1.37-22.10$ & $0.02 *$ \\
\hline
\end{tabular}

SE: status epilepticus; OR: Odds Ratio; \%: percentage; $95 \% \mathrm{Cl}$ : confidence interval; ${ }^{*} p \leq 0.05$

Table 4. Cox regression on factors relating to development of healthcare-associated infections and survival at three months among Ecuadorian patients with status epilepticus.

\begin{tabular}{lccc}
\hline Factors & OR & $95 \% \mathrm{Cl}$ & $\mathrm{p}$-value \\
\hline $\begin{array}{l}\text { Healthcare-associated } \\
\text { infections }\end{array}$ & 2.23 & $1.08-4.58$ & $0.03^{*}$ \\
$\begin{array}{l}\text { Factors relating to healthcare- } \\
\text { associated infections }\end{array}$ & & & \\
\hline $\begin{array}{l}\text { Infection site } \\
\text { Disseminated infection }\end{array}$ & 0.79 & $0.57-1.09$ & 0.15 \\
\hline Type of bacteria & 1.58 & $0.69-3.61$ & 0.28 \\
\hline Gram-negative bacteria & 3.17 & $0.84-1.36$ & 0.60 \\
\hline Multidrug-resistant bacteria & 1.56 & $0.64-3.76$ & 0.32 \\
\hline Mechanism of resistance & & & $0.02 *$ \\
\hline ESBL & 2.32 & $0.98-5.51$ & 0.06 \\
\hline CPB & 3.09 & $1.30-7.34$ & $0.01 *$ \\
\hline
\end{tabular}

OR: Odds Ratio; $95 \% \mathrm{Cl}$ : 95\% confidence interval; ${ }^{*} \mathrm{p} \leq 0.05$; ESBL: extendedspectrum beta lactamase; CPB: carbapenemase-producing bacteria.

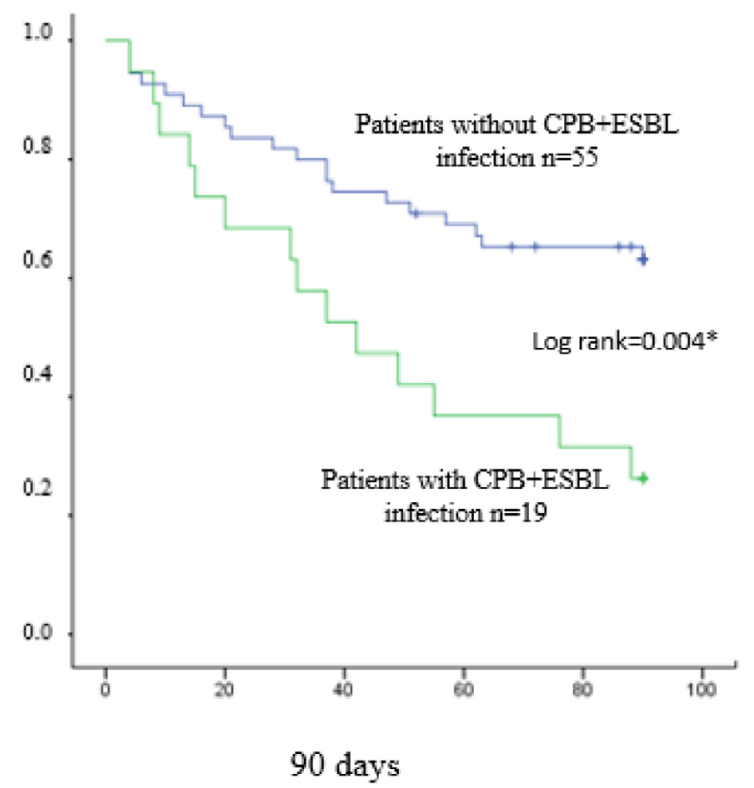

HCAls: healthcare-associated infections; CPB: carbapenem-producing bacteria; ESBL: extended-spectrum beta lactamase.

Figure 2. Kaplan-Meier survival analysis on Ecuadorian patients with status epilepticus, according to presence of healthcareassociated infections and drug-resistant mechanism. 


\section{DISCUSSION}

Over the last decade, a few investigations on the relationship between HCAIs and SE have been conducted. It is already known that presence of HCAIs is linked to prolonged hospitalization, severity of illness and increased resource utilization $^{5}$. Subsequent studies have demonstrated that infections have a negative impact on the course and outcomes of $\mathrm{SE}^{3,4}$. Infections within the first 72 hours of SE have been correlated with longer duration of SE, higher rates of RSE and mortality ${ }^{3}$. Even in patients with SE of less severe etiology, sepsis has been associated with poor outcomes ${ }^{16}$.

The rate of sepsis in patients with SE has ranged from 28 to $48 \%$ in different studies ${ }^{3,4,16}$. In our study, the rate of HCAIs reached $56.1 \%$, i.e. higher than in previous studies. Our findings suggest that HCAIs in patients with SE could be a problem of greater magnitude in developing countries than in developed countries. Projects to determine the incidence of HCAIs in patients with SE and identify preventive strategies are needed.

Several factors predispose towards development of HCAIs in patients with SE, for example: loss of consciousness caused by sedative drugs, use of mechanical ventilation, use of catheters, prolonged hospitalization, RSE and comorbidities. In our opinion, the severity of SE may be a factor that predisposes towards HCAIs. Patients with greater severity of SE required longer sedative treatment, extended mechanical ventilation, prolonged hospitalization in neuro-intensive care units and, more often, invasive procedures (tracheostomy, gastrostomy or use of a central catheter, among others).

The mortality rate (in hospital and at three months) in our investigation was higher than in studies carried out in European settings (36 vs $25.6 \%$ found by Sutter, $26 \%$ by Semmlack and $2 \%$ by Zelano) $)^{3,4,16}$. We hypothesize that differences in mortality rates are a consequence of dissimilar characteristics of samples (etiology, complications and severity SE) and the limited resources found in developing countries (lack of continuous electroencephalography monitoring and use of second-line antiepileptic drugs, among others). Specifically, among patients with SE and HCAIs, the mortality rate at three months was $62 \%$ and Kaplan-Meier analysis found a significantly reduced survival rate. Similar findings were reported in previous studies ${ }^{3,4}$, including those in which the synergic influence of SE and the systemic inflammatory response caused by infections and its role in disruption of the blood-brain barrier were investigated ${ }^{4,17,18}$. It has been suggested that the cytotoxic effects of excitatory neurotransmitters during SE add to the pro-inflammatory factors (interleukins, immune cell, tumor necrosis factor alpha, nitric oxide and glutamate) due to SE and infections, and that this could be the basis for neuronal damage ${ }^{4,19,20}$. In our opinion, new guidelines for $\mathrm{SE}$ treatment should include recommendations for early diagnosis and treatment of infectious complications, as previously mentioned by Semmlack et al ${ }^{4}$.

One strength of our study was that we analyzed the specific factors related to HCAIs. Mortality was significantly increased among patients with infections caused by Gram-negative bacteria and CPB. To our knowledge, no previous studies have focused on the factors associated with HCAIs (type of germs, Gram stain classification and mechanism of resistance) and their impact on the final outcomes among patients with SE. An additional strength of this study is its analysis on factors associated with HCAIs and their influence on outcomes among SE patients. It may be possible to confirm these findings through use of larger samples and multicenter studies.

One limitation of this study was its observational singlecenter design and relatively small sample. Furthermore, we consider that SE is a complex disorder and, thus, by simplifying the outcomes among patients to only one factor, the interpretation of the results is limited. Additionally, determining the attributable independent risk of any one factor among patients with SE is complicated. The clinical spectrum of $\mathrm{SE}$ is diverse and multiple variables are involved in the final outcomes of patients. Therefore, we suggest that caution is needed in drawing conclusions from the results of this study.

In conclusion, HCAIs were found to be a common complication in Ecuadorian patients with SE that correlated with a lower survival rate at three months. Prolonged hospital length of stay, RSE and Charlson comorbidity index $\geq 2$ were associated with the risk of developing HCAIs. Infections caused by Gram-negative and carbapenemase-producing bacteria were linked to an increased risk of mortality at 90 days.

HCAIs need to be promptly identified and treated and their additional influence on the risk of mortality among patients with SE should not be underestimated.

\section{References}

1. Betjemann JP, Josephson SA, Lowenstein DH, Burke JF. Trends in status epilepticus-related hospitalizations and mortality: redefined in US practice over time. JAMA Neurol. 2015 Jun;72(6):650-5. https:// doi.org/10.1001/jamaneurol.2015.0188

2. Busl KM. Nosocomial infections in the neurointensive care unit. Neurol Clin. 2017 Nov;35(4):785-807. https://doi.org/10.1016/j.ncl.2017.06.012

3. Sutter R, Tschudin-Sutter S, Grize L, Fuhr P, Bonten MJM, Widmer AF, et al. Associations between infections and clinical outcome parameters in status epilepticus: a retrospective 5-year cohort study. Epilepsia. 2012 Sep;53(9):1489-97. https://doi.org/10.1111/j.1528-1167.2012.03576.x
4. Semmlack S, Tschudin-Sutter S, Widmer AF, Valença M, Rüegg S, Marsch S, et al. Independent impact of infections on the course and outcome of status epilepticus: a 10-year cohort study. J Neurol. 2016 May;263(7):1303-13. https://doi.org/10.1007/s00415-0168140-1

5. Ala-Kokko TI, Säynäjäkangas P, Laurila P, Ohtonen P, Laurila JJ, Syrjälä $\mathrm{H}$, et al. Incidence of infections in patients with status epilepticus requiring intensive care and effect on resource utilization. Anaesth Intensive Care. 2006 Oct;34(5):639-44. https:// doi.org/10.1177/0310057×0603400509 
6. Allegranzi B, Nejad SB, Combescure C, Graafmans W, Attar H, Donaldson L, et al. Burden of endemic health-care-associated infection in developing countries: Systematic review and metaanalysis. Lancet. 2011 Jan;377(9761):228-41. https://doi. org/10.1016/s0140-6736(10)61458-4

7. Trinka E, Cock H, Hesdorffer D, Rossetti AO, Scheffer IE, Simon S, et al. A definition and classification of status epilepticus - Report of the ILAE Task Force on Classification of Status Epilepticus. Epilepsia. 2015 Oct;56(10):1515-23. https://doi.org/10.1111/epi.13121

8. Leitinger M, Beniczky S, Rohracher A, Gardella E, Kalss G, Qerama E, et al. Salzburg Consensus Criteria for Non-Convulsive Status Epilepticus - approach to clinical application. Epilepsy Behav. 2015 Aug;49:158-63. https://doi.org/10.1016/j.yebeh.2015.05.007

9. Brophy GM, Bell R, Claassen J, Alldredge B, Bleck TP, Glauser T, et al. Guidelines for the evaluation and management of status epilepticus. Neurocrit Care. 2012 Aug;17(1):3-23. https://doi.org/10.1007/s12028012-9695-z

10. Teasdale G, Jennett B. Assessment of impaired consciousness and coma: a practical scale. Lancet. 1974 Jul;2(7872):81-4. https://doi. org/10.1016/s0140-6736(74)91639-0

11. Commission on Epidemiology and Prognosis ILAE. Guidelines for Epidemiologic Studies on Epilepsy. Epilepsia. 1993 Jul;34(4):592-6. https://doi.org/10.1111/j.1528-1157.1993.tb00433.x

12. Charlson ME, Pompei P, Ales KL, MacKenzie RC. A new method of classifying prognostic comorbidity in longitudinal studies: development and validation. J Chronic Dis. 1987;40(5):373-83. https://doi.org/10.1016/0021-9681(87)90171-8
13. Lowenstein $\mathrm{DH}$. The management of refractory status epilepticus: An update. Epilepsia. 2006 Oct;47(Suppl.1):35-40. https://doi. org/10.1111/j.1528-1167.2006.00658.x

14. Garner JS, Jarvis WR, Emori TG, Horan TC, Hughes JM. No CDC definitions for nosocomial infections, 1988. Am J Infect Control. 1988 Jun;16(4):818-27. https://doi.org/10.1016/0196-6553(88)90053-3

15. Rankin J. Cerebral vascular accidents in patients over the age of 60. II. Prognosis. Scott Med J. 1957 May;2(5):200-15. https://doi. org/10.1177/003693305700200504

16. Zelano J, Möller F, Dobesberger J, Trinka E, Kumlien E. Infections in status epilepticus: A retrospective 5-year cohort study. Seizure. 2014 Sep;23(8):603-6. https://doi.org/10.1016/j.seizure.2014.04.012

17. Sutter R, Grize L, Fuhr P, Rüegg S, Marsch S. Acute-phase proteins and mortality in status epilepticus: a 5-year observational cohort study. Crit Care. 2013 Jun;41(6):1526-33. https://doi.org/10.1097/ ccm.0b013e318287f2ac

18. Sutter R, Tschudin-sutter S, Grize L, Widmer AF, Marsch S, Rüegg $\mathrm{S}$. Acute phase proteins and white blood cell levels for prediction of infectious complications in status epilepticus. Crit Care. 2011 Nov;15(6):R274. https://doi.org/10.1186/cc10555

19. Heinemann UWE, Kaufer D, Friedman A. Blood-brain barrier dysfunction, TGF $\beta$ signaling, and astrocyte dysfunction in epilepsy. Glia. 2012 Aug;60(8):1251-7. https://doi.org/10.1002/glia.22311

20. Montgomery SL, Bowers WJ. Tumor necrosis factor-alpha and the roles it plays in homeostatic and degenerative processes within the central nervous system. J Neuroimmune Pharmacol. 2012 Mar;7(1):42-59. https://doi.org/10.1007/s11481-011-9287-2 